\title{
АКТУАЛЬНА ТЕМА
}

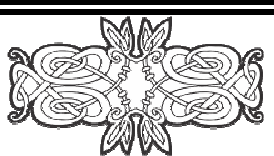

ACTUAL THEME

\author{
УДК 657.471 \\ JEL Classification M41
}

\author{
Пушкар Михайло \\ д.е.н., профресор \\ кафредра аудиту, ревізії та аналізу \\ Тернопільський національний економічний університет \\ м. Тернопіль, Україна \\ E-mail: M.S.Pushkar@gmail.com \\ Семанюк Віта \\ к.е.н., доцент, докторант \\ кафедра аудиту, ревізії та аналізу \\ Тернопільський національний економічний університет \\ м. Тернопіль, Україна \\ E-mail: v.semaniuk@tneu.edu.ua
}

\section{АКТУАЛЬНІСТЬ РОЗРОБКИ СУЧАСНОЇ ПАРАДИГМИ ОБЛІКУ}

\section{Анотація}

Bступ. Суспільство і бізнес не можуть існувати без облікової системи, яка збирає фракти про фрінансову та господарську діяльність бізнесу на мікроекономічному рівні та перетворює їх у корисну інформацію для менеджменту підприємства. Проте, існуюча модель єдиного «бухгалтерського обліку» застаріла внаслідок застосування ним лише одного методу подвійного запису ігноруючи необмежені можливості збору й обробки даних й отримання інформації за допомогою сучасних комп'ютерних технологій - блокчейна, хмарних обчислень, штучного інтелекту та інших що вимагає розробки нової парадигми.

Meтоди. Опрацювання матеріалу статmі стало можливим на основі використання таких методів як філософрія пізнання, зокрема, законів діалектики, логіки, історичного, соціологічного та системного підходів до аналізу науки про облік та її парадигми, прогнозування розвитку обліку, як складної динамічної системи, фрактори консерватизму облікового співтовариства.

Результати. Аналіз історичного процесу розвитку науки і практики облікового знання в Україні засвідчує його неадекватність умовам економічного укладу, який складається після 1991 року. Парадигма обліку зберігає риси минулої епохи. Вона базується на ідеології ручної обробки даних та отримання інформації у грошовому вимірнику в цілому по підприємству. Така інформація дозволяє підтримувати лише функцію управління фінансами. Для управління господарською діяльністю на операційному і стратегічному рівнях «бухгалтерський облік» не дає практично ніяких повідомлень, тому стару парадигму обліку повинна замінити нова. Система повинна генерувати інфрормацію для усіх рівнів менеджменту. Оскільки у менеджерів різні потреби в інформації за часом, структурою та обсягом, то розробка нової інфрормаційної парадигми повинна спрямовуватися на створення складної динамічної системи з підсистемами фрінансового, управлінського і стратегічного обліку. Крім цього, без зміни назви науки на «інформологію» (вчення про інформацію) замість «бухгалтерський облік» (записи у книги), «стара гвардія» бухгалтерів психологічно ніколи не буде готова інтелектуально сприйняти зміни у привичному способі мислення і діяльності. Отже, без революційних змін у парадигмі, облік приречений і надалі залишитися ремеслом або, у кращому випадку, мистеитвом записів у книги і звітні фрормуляри.

Перспективи. Розвиток облікової науки неможливий без переорієнтації із стереотипного набору правил обробки даних для складання фрінансової звітності на систему отримання інформації інтелектуального рівня для 
управління. Для такої переорієнтації актуальною проблемою стає формування розвинутої теорії обліку на принципах теорії пізнання та інфоорматики.

Ключові слова: наука, діалектика, парадигма, система обліку, мислення бухгалтерів, підсистеми обліку, інсрормологія.

\section{Вступ.}

У відповідності до законів діалектики все у світі з часом змінюється, а тим більш, у складній динамічній системі, якою $є$ суспільство. По мірі зростання населення країни міняються умови і закони, що обумовлюють функціонування економічного базису і його надбудови. Зміни стосуються усіх інституцій суспільства та їх взаємовідносин. Одні 3 них змінюються досить швидко (революційним шляхом), а інші - поступово (еволюційним), але у першому і другому випадках внаслідок змін перероджуються усі системи суспільства без виключення.

Проте, в силу консерватизму, властивому обліковим працівникам, система обліку змінюється вкрай повільними темпами. Якщо такі зміни є, то, скоріш за все, вони формальні (наприклад, уточнення час від часу плану рахунків, реквізитів документів, форм обліку тощо), які не стосуються фундаментальних проблем бізнесу та ролі обліку в ньому, про що свідчить зміст таких фундаментальних робіт як [1], авторами якої є вітчизняні та іноземні автори, не говорячи про праці інших авторів.

Проблема осучаснення системи обліку з кожним роком стає все більш актуальною для українського суспільства, оскільки її архаїчність і невідповідність потребам бізнесу вражає. Вона відбиває рівень розвитку науки і потреби практики бізнесу індустріальної епохи кінця XУІІІ ст., коли принцип подвійного запису досяг свого апогею. Парадигма обліку подвійного запису після свого розквіту на початку XIX ст. стає об'єктом критики менеджерів через її неспроможність дати реальну допомогу менеджерам в управлінні середнім і великим бізнесом.

Розробка нової парадигми обліку назріла давно, але стараннями наукового співтовариства обліковців зберегти застарілий зміст науки під назвою «бухгалтерський облік», робить марними намагання новаторів перебороти консерваторів «старої гвардії» 3 їх метафізичним мисленням і традиціями обліку минулої епохи та небажанням за будь - яких обставин поступитися догматами облікового ремесла.

\section{Аналіз останніх досліджень і публікацій.}

Достатньо ознайомитися зі змістом підручників і посібників, присвячених «Основам бухгалтерського обліку», щоб упевнитися наскільки примітивною $є$ той сурогат, який в насмішку над здоровим глуздом, називають теорією. 3 року в рік така література поповнюється все новими «шедеврами» маловідомих авторів, які бездумно та в гірших варіантах, ніж відомі авторитети Ф.Ф.Бутинець [2], М.Т.Білуха [3], В.І Валуєв [4] Н.М.Ткаченко [5], В.В. Сопко [6], В.Г.Швець [7] та інші доктори наук, відтворюють стандартний заяложений зміст облікового знання, позбавленого справжньої науковості. Низький рівень облікової освіти негативно позначається на практичній діяльності працівників облікової сфери, неспроможних взаємодіяти з менеджерами щодо розвитку інформаційної культури бізнесу. Причина такого положення з обліком полягає у використанні на практиці старої парадигми, сутність якої полягає виключно у застосуванні подвійного запису, що обмежує інформаційне поле одним видом обліку - фінансовим. Розширення інформаційного поля бізнесу вимагає створення нової парадигми обліку, сутність якої - сервісне інформаційне обслуговування системи менеджменту.

Проблемою формування і розвитку облікових парадигм в Україні займається невелика когорта науковців, серед яких В. М. Жук [8], Н. М. Малюга [9], С. Ф. Легенчук [10], М.С. Пушкар [11], Р.Ф.Бруханський [12], В.З.Семанюк [13] та інші автори, які відзначають незадовільний стан розвитку обліку в державі та необхідність доповнення фінансового обліку підсистемами управлінського і стратегічного. 


\section{Мета.}

Мета статті полягає в організації наукової дискусії про можливі напрями формування нової парадигми обліку і на ії основі створення інтелектуальної теорії інформаційного менеджменту підприємства. з метою удосконалення практики отримання інформаційних ресурсів для бізнесу.

\section{Методологія дослідження.}

Методологія дослідження базується на синтезі знань з філософії, зокрема, законів діалектики, наукознавства, теорії пізнання, соціології, структури та економіки підприємств, інформаційних процесів на підприємстві, теорії менеджменту, системології та інших наук, що сприяють формуванню абстрактного образу облікової науки, здатної підняти практику інформаційної сфери на якісно вищий рівень.

\section{Результати.}

Діюча система обліку не відповідає очікуванням українського суспільства через її архаїчну природу i невиконання нею сервісних функцій з обслуговування управлінського апарату підприємства необхідним обсягом інформації. Це стало наслідком недосконалих освітніх програм 3 облікових дисциплін. Примітивізм міркувань щодо ролі обліку, пояснення змісту дисципліни на рівні інтелекту школярів, довільне тлумачення облікової термінології без належної логіки та наукового доведення, схоластика викладання, бюрократичний стиль мови, канцеляризми та інші недоліки методичного плану, не говорячи вже про науковість, властиві чи не $90 \%$ книг з «теорії обліку» позбавлені теорії у високому значенні цього слова.

Навіть у випадках захисту толкових кандидатських і докторських дисертацій, висновки та пропозиції яких у сукупності могли би слугувати основою розробки розвинутої теорії, їх автори збиваються у своїй подальшій роботі на традиційно погану програму «Основ бухгалтерського обліку».

Чи багато науковців (якщо вони науковці не за дипломом, а за своїм покликанням, інтелектом й ерудицією) задумувався над тим, чому в економічно розвинутих англомовних країнах традиційний облік - bookkeeping (аналог нашого «бухгалтерського») доповнили принципово іншим обліком під назвою accounting (аналога якому в нашій мові немає)?

А це сталося тому, що bookkeeping (ведення книг бухгалтером) вимагає виконання рутинної і стереотипної роботи з цифрами, у той час, як accounting (не перекладається на українську), означає вищий рівень творчої роботи менеджера інформаційної ссрери, який одночасно виконує функції економіста, бухгалтера, аналітика, контролера, фінансиста. Такий спеціаліст синтезує знання, а в нашій практиці спеціалісти виконують лише одну функцію - записи кореспонденції рахунків у книги. Різниця між роботою клерка й інформаційного менеджера досить очевидна, оскільки замість наших кількох спеціалістів вузького профрілю, зосереджених на одній вузькій функції, в таких країнах, як США, Англія чи інші, їх може замінити один фрахівець з широким діапазоном функцій.

Через відсутність в українській мові аналогу слова accounting, вся англомовна література 3 цим словом перекладається у нас як «бухгалтерський облік», що є грубою підміною понять та викривленням сутності облікової науки. Це свідчить про те, що хочемо ми, чи не хочемо, але заради комунікацій з колегами інших країн і розуміння тенденцій подальшого розвитку науки про облік в інформаційному суспільстві, необхідно уводити в науковий оборот нові слова, адекватні новим реаліям у роботі менеджерів та готувати потрібну для них інформацію на основі необмежених можливостей процесів обробки даних.

Логіка пізнання закономірності розвитку облікової сфрери свідчить про її залежність від середовища бізнесу, яке постійно змінюється, тому необхідно вирішувати проблему створення системи обліку, здатної реагувати на нові ситуації в бізнесі, збирати факти в реальному часі й давати релевантну інформацію користувачам. 
На жаль, відстала від вимог науки і практики парадигма обліку позбавляє бізнес інфоормації, як одного з факторів виробництва та управління. Традиційна «теорія» не має перспектив розвитку внаслідок утрати нею зв'язку з тим предметом, який вона призначена вивчати - а саме, з інформаційними процесами у їх широкому розумінні, як здатності до творчого пошуку актуальної інформації для бізнесу.

Більшість науковців розуміють облік лише в його процедурному аспекті, коли стереотипний набір алгоритмів збору даних та їх обробки за відомими сотні років методами середньовіччя (фіксація фрактів господарської діяльності в документах, оцінка фактів, групування їх за певними критеріями, записи у стандартні регістри на основі складеної кореспонденції рахунків та відображення згорнутої (узагальненої) інформації у фінансовій звітності із стандартним набором економічних показників).

Роботу бухгалтера на основі такого «наукового базису» не можна назвати творчою, оскільки вона базується на виконуваних циклічно, з місяця в місяць, рутинних процедурах, що характерно для ремесла. Якщо описування процедур роботи бухгалтера (записи у книги), назвати теорією обліку, то закономірно виникає питання, а що тоді називається ремеслом?

3'ясування питання «що таке наука?» неможливо в межах знань фахівців з обліку оскільки це не їх проблематика, тому необхідно звернутися до тих фрахівців, які вивчають загальні проблеми теорії пізнання, а її висновки потрібно використати для розробки теорії обліку.

Проблеми теорії науки на високому абстрактному рівні вивчають філософи та наукознавці, а не бухгалтери, котрі не дуже або й зовсім не обізнані з тонкими матеріями теорії пізнання, але досить часто беруть на себе сміливість конструювати теорію на свій смак і розсуд описуючи послідовні дії практиків облікового процесу, звідки й появилася «теорія подвійного запису» в епоху пізнього середньовіччя і в такому застиглому вигляді дійшла до наших днів.

Відомо, що бухгалтери, в силу специфіки свого ремесла, не люблять процесу філософування, уважаючи його не гідним і пустопорожнім заняттям послуговуючись одним принципом здорового глузду, а іноді й без нього, відтворюючи облікові знання на основі емпіричних даних існуючої недосконалої практики, тим самим зводячи облікову науку до простого ремесла.

Не вірно інтерпретуючи тезу, що практика $є$ критерієм істини, бухгалтери свято вірять у шаблони недосконалої практики, а науковці зводячи канони практики в ранг теорії, попадають в замкнуте коло: існуюча практика породжує адекватну їй теорію, а теорія відтворює стару практику. Бухгалтери не можуть вийти з наїждженої колії і тому парадигма подвійного запису не міняється більше 500 років.

Розімкнути замкнуте коло не можна на містичній вірі у непохитність канонів подвійного запису (а саме це проповідують до цього часу бухгалтери і в ї уяві так було, так є і так буде навіки віків!). Дійсно: так було і так поки що є, але так далі не буде!

Не принцип віри чи не віри у стародавні канони обліку, а діалектика руху і змін матеріального світу, глибина пізнання людьми закономірностей розвитку природи, суспільства і мислення дають поштовх для розширення горизонту знань та їх застосування на практиці. Сила знань, набутих у процесі розвитку суспільства і зафіксованих у теорії науки, впливають у не меншій, а можливо й більшій мірі на практику, ніж практика на теорію. Проте, істинність досягнень теорії може бути перевірена і доведена тільки на практиці.

Отже, між практикою і теорією завжди існує взаємодія, коли на першому з історичних етапів розвитку науки переважає практика даючи емпіричний матеріал для узагальнення ї̈ надбання в теорії, а на інших етапах - теорія акумулює знання різних наук і розширює застосування існуючих та генерування i застосування нових методів дослідження випереджуючи практику й активно впливаючи на неї.

На жаль, теорії обліку, а також теорії контролю до цього часу не розроблено, тому облікова наука не може запропонувати щось цінне для розвитку інформаційної практики. 
Якщо когось з моїх колег обліковців висновки щодо відсутності теорії обліку не переконують і ображають, а таких за нашими даними переважна більшість (хоча, безперечно, $€$ й такі науковці, які послуговуються надбанням теорії пізнання і філософії, хоча їх чисельність надзвичайно мала), то я готовий довести їм, що у фрілософії вони профани (профан - це не образа, а ступінь ерудиції (у стародавньому Римі це слово означало непосвячену особу, що не мала права входити до храму). У нашому випадку ми маємо на увазі непосвячену у філософрію людину, яка не має права входити до храму науки, оскільки без допомоги філософії неможливо вияснити сутність поняття «наука» і встановити той фракт, чи відповідає облік критеріям науки. Для формування і функціонування науки важливими елементами виступають:

- обов'язкове включення загальних законів розвитку теоретичного знання, розробка концепцій, принципів, понять, теорем, аксіом, моделей та інших необхідних атрибутів пізнання дійсності. Проте, в обліку більшість 3 цих понять не те що не були розкриті до цього часу, а й не досліджуються науковцями в наші дні. Замість фрормування категорійного апарату облікової науки та розробки ії концепції, науковці на вербальному рівні у примітивній формі розповідають про те, що роблять клерки (бухгалтери) на практиці при зборі та обробці фактів господарської діяльності та що і в які книги чи регістри записують, тому облік знаходиться скоріше на стадії ремесла, ніж науки;

- оперування деяким набором об'єктивно необхідних положень і виявлення закономірностей процесу формування інформації про фінансово - господарську діяльність підприємства. Наука повинна пояснювати дію окремих фрактів та їх сукупностей на досліджувані явища і процеси господарської діяльності. Оскільки облік, на жаль, не ставить за мету виявлення закономірностей і тенденцій розвитку економічної діяльності підприємства на основі аналізу отриманої інфрормації, то процес пізнання дійсності не дуже й цікавить облікових працівників, які всю увагу та енергію зосереджують на стандартних засобах і процедурах з обробки даних, а не змістовому наповненні отриманих інформаційних ресурсів для менеджменту 3 урахуванням можливого використання отриманих повідомлень про зміни внутрішнього і зовнішнього середовищ для адаптації бізнесу до них;

- формування розвинутого категорійного апарату. Категорії виражають і фріксують найзагальніші сторони пізнавального процесу. Проте, в теорії обліку категорійний апарат надто бідний і не відповідає статусу розвинутої науки. Він практично залишається неупорядкованим та обмеженим з позицій наукознавства. Більшість категорій часто не піддаються визначенню в межах облікової теорії, тому їх потрібно запозичувати з інших наук і використовувати для ув'язки знань конкретних наук з філософією і філософії з конкретними науками. На жаль, переважна більшості науковців з обліку, а тим більш, практикуючих бухгалтерів, не використовують надбання теорії пізнання у своїх дослідженнях обмежуючись емпіричними даними і процедурами збору й обробки даних на основі власного досвіду і здорового глузду. Проте, здоровий глузд ні в якій мірі не може замінити теорію науки;

- теорія науки повинна бути об'єднана загальною основою. У якості такої основи можна прийняти концепцію, парадигму чи систему, в яких виділяють: підсистеми; елементи; зв'язки і взаємодію між ними; субординацію; ієрархічні рівні; входи, процесор і виходи в оточуюче середовище тощо. Елементи теорії систем в обліковій науці практично не досліджені, а науковці не застосовують їх у своїх публікаціях, тому облік вони уявляють як щось аморфне, як набір столярних інструментів за допомогою яких обробляють деревину перетворюючи її на меблі. Подібно до цього облік поки що не набув ознак цілісної системи з їі підсистемами, а існує як набір процедур, за допомогою яких зібрані дані трансформують у наперед формально визначені обсяги і структуру інформації стандартного змісту. За таких умов не можна визнати облік розвинутою галуззю знань.

- положення науки хоча й виконуються суб'єктами (людьми), але вони повинні бути доведені об'єктивною основою (реальними, істинними властивостями речей, явищ і процесів, які відбуваються у природі, суспільстві чи мисленні людини) Проте, в обліку переважає суб'єктивізм, 
умовності та стереотипні методи отримання інформації обмеженого інтелектуального значення, що $€$ парадоксом в епоху інформаційних технологій, коли з обмежених даних можна отримати необмежний обсяг інформації для менеджерів комбінуючи дані в різних ракурсах у просторі й часі;

- наука виконує прогностичну функцію, на основі якої система управління передбачає майбутні події у фрінансово - господарській діяльності підприємства. Однак, в силу історичних та соціальних причин, облік поки що не включає у сферу своїх інтересів стратегічну підсистему. Нехтування обліковцями прогностичної функції науки позбавляє менеджерів інформації про майбутній стан бізнесу та унеможливлює зниження рівня невизначеності середовища і своєчасне реагування на ризики і загрози підприємству. Менеджери вищого рівня управління вимагають від обліковців інформації особливого роду, яка необхідна для прогнозування розвитку підприємства. Раніше такої інформації для бізнесу не готувала ні одна економічна служба, але в наші дні неможливо собі уявити існування бізнесу без знання процесів, які відбуваються у зовнішньому середовищі, коли виникає загроза підприємству. Поява стратегічного обліку $є$ наслідком закономірного історичного процесу розвитку економіки. Відсутність стратегічного обліку свідчить про відставання і відірваність облікової науки від практики, яка позбавлена не тільки нових ідей, адекватних реаліям інформаційного суспільства, а й здорового глузду через нехтування можливостями сучасної обчислювальної техніки та цінністю інформаційних ресурсів для бізнесу. Розвиток можливий тільки на основі досягнень науки, техніки, технології, організації та управління виробничими системами;

- кардинальні зрушення в економічній системі вимагають формування нової парадигми обліку. Отримання інформації для відстеження тенденцій розвитку бізнесу можливо за рахунок створення автономних, але взаємодіючих, трьох підсистем загальної системи обліку за критерієм часу - про минулі, сучасні та майбутні події господарської діяльності. Зрозуміло, що потрібні для цього три автономні підсистеми загальної системи обліку, які генерують одночасно інформацію для задоволення потреб трьох рівнів менеджменту - нижчого, середнього і вищого або за словами Ікудзіро Нонаки - подання інформації за принципом «середина - верх - низ» [14].

Отже, за критеріями наукознавства, які визначають статус розвинутої науки, теорія господарського обліку не відповідає високому слову «наука». Незважаючи на те, що облік має кількатисячну історію, він поки що зберігає риси мистецтва записів у книги та відображає рівень знань минулої епохи розвитку суспільства (XIV - XV ст. - пізнього середньовіччя) і не має сучасного теоретичного обірунтування.

Одне із основних завдань облікової науки полягає в прокладанні шляхів для розвитку практичної діяльності та удосконаленні методів роботи облікового апарату щодо отримання такого обсягу інформації, якої вимагають менеджери усіх рівнів системи управління, але облік не виконує цієї функції, оскільки не дає актуальних в даний час і прогнозованих повідомлень про бізнес процеси і тенденції розвитку бізнесу.

Практика свідчить про те, що відсутність інформації для менеджерів операційного рівня, в якому відбуваються реальні економічні події з трансформації факторів виробництва у готовий продукт і зароджується майбутній фінансовий результат, призводить до вимушеного пошуку ними будь - яких даних, як правило, несистемного і випадкового характеру, що життєво важливі для контролю за формуванням собівартості продукції в реальному часі, оскільки керівники нижчого рівня управління безпосередньо відповідають за виконання календарних планів роботи підприємства.

На жаль, до цього часу бухгалтери не зрозуміли ролі та значення інформаційних ресурсів для ефрективного функціонування бізнесу, зокрема таких його складових як управлінське планування, облік, аналіз та контроль діяльності на основі нормування витрат, доходів та фінансових результатів за центрами витрат (підрозділами підприємства) та сферами відповідальності (матеріально - відповідальними особами, відповідальними за витрачання окремих видів ресурсів у місцях (центрах) витрат. До речі, науковці не розібралися у термінології і внесли 
плутанину в поняття «центр» і «сфрера чи зона відповідальності» неправомірно ототожнюючи їх, про що свідчать практично всі публікації авторів з проблеми обліку витрат, а це характеризує рівень володіння ними науковим апаратом облікової науки.

У все більшій мірі менеджери вищого рівня управління відчувають недостатність прогнозної інформації, яка набуває особливого значення для розробки стратегія розвитку підприємства на кілька років наперед, але діюча система обліку, в принципі, не дає і не може дати ніякої моделі відображення фактів господарської діяльності на тривалу перспективу. На підприємствах Україні 3 початку 2000 р., панує офріційний фінансовий облік, який за недоброю традицією називають «бухгалтерським». Сила стереотипів мислення настільки живуча, що здається ії ніколи, ніщо і ніхто не здолає!

Аналіз причин недосконалості основ облікової науки (а насправді треба розуміти відсутність загальної теорії обліку, як складної системи знань з виділенням окремих підсистем отримання інформаційних ресурсів про фінансову і господарську діяльність підприємства), дає можливість установити ті фрактори, які сприяють чи перешкоджають розвитку облікової науки.

Серед причин живучості парадигми подвійного запису на перше місце потрібно поставити фактори об'єктивного характеру - суспільно - історичні та психологічні, коли у часи середніх віків сформувалася парадигма подвійного обліку, яка дійшла до наших днів і за якою навчають нові покоління бухгалтерів. Незважаючи на можливості розширення методологічного апарату досліджень проблем обліку з використанням високопродуктивної комп'ютерної техніки, організація і методи отримання інформації залишаються тими ж, що й до появи комп'ютера. Сила облікової традиції переважає силу логіки і науки, які доводять необхідність зміни облікового процесу 3 ремесла, яким воно $є$ зараз, на високий статус науки. Свідоме чи несвідоме гальмування процесу перетворення облікового ремесла в розвинуту науку в Україні, не можна назвати інакше, як відсутністю державної політики щодо регулювання економіки і маніакальною впертістю бухгалтерів залишити привичний примітивний облік, а також опором усьому новому з боку тих «науковців», які сповідують принципи середньовічного «бухгалтерського обліку».

В основу застарілої парадигми «бухгалтерського» обліку (якого відкидає економічне життя, оскільки навчальні заклади дають студентам зміст, принаймні, двох підсистем обліку фінансового та управлінського), покладено набір стандартних рахунків, сукупність документів для фіксації здійснених фактів господарської діяльності, які після їх обробки записують у стандартні регістри, а підсумки переносять у Головну книгу та стандартні форми фінансової звітності. Така робота раніше виконувалася ручним способом за допомогою арифмометра і рахівниці, а тепер та сама робота - за допомогою комп'ютера. Незважаючи на науково-технічний прогрес, обліковий цикл та його складові залишаються, за своєю сутністю незмінними. Традиційний підхід ґрунтується на ідеї, що стара парадигма не вичерпала своїх можливостей і її можна адаптувати до нових вимог економіки, але виникає питання, як усунути протиріччя, що виникли в нормальній науці?.

Інноваційний підхід до формування нової парадигми полягає у тому, що з однієї нормальної науки може народжуватися кілька нових, що є об'єктивним процесом пізнання, у відповідності до якого в науці відбувається диференціація (поділ, декомпозиція) та інтеграція (об'єднання) наук.

Проте, більшість дослідників шукають компромісу між науковими школами, орієнтуючись на еволюційний шлях розвитку облікової науки, хоча відомо, що криза тому й настала, що еволюційні зміни у ній вже переросли у революційні, коли кількісні зміни у системі переросли у якісні.

3 філософської точки зору розвиток системи обліку в умовах революції (друга половина XX - початок XXIст.) заперечує традиційний та еклектичний підходи до формування нової парадигми і пов'язує його з інноваційним підходом (нагромадження критичного обсягу ідей, гіпотез, проблем та їх узгодження між собою.

Враховуючи загальні тенденції прискореного зростання економіки, яка потребує нової парадигми обліку, в найближчій перспективі, можна очікувати активізації наукової діяльності у співтоваристві бухгалтерів. Для цього потрібно залучити велику кількість кандидатів і докторів наук 
до вирішення проблеми створення нової парадигми обліку, які можуть свідомо фрормувати наукові дослідження в руслі інноваційного підходу.

На основі вчення Т.Куна [15] автори статті здійснили аналіз історії розвитку облікових знань, що дало можливість виявити етапи формування нової парадигми науки.

Будь - які знання в суспільстві своїм корінням заглиблюються у стародавні часи і виникають з практичних міркувань. Не стали винятком і знання з обліку, коли виникла практична необхідність робити несистематизовані записи, що стосувалися володіння й обміну майна в окремих випадках. Згодом такі записи стали правилом у храмах і царських володіннях. Поява товаро-грошових відносин стимулювала пошук простої моделі обліку, яка набуває завершених форм у пізньому середньовіччі. У період формування індустріальної формації облік набуває сучасного образу і розвивається на принципах нормальної науки, хоча й зберігає початкову парадигму подвійного запису. Поступово проявляються недоліки і протиріччя нормальної науки до того часу, поки не настає криза парадигми обліку середніх віків, яка може бути подолана лише революцією в науці та формуванням нової парадигми. Якраз ми живемо в епоху кризи, коли облік подвійного запису сковує ініціативу новаторів, які пропонують отримувати інформацію за допомогою різноманітних методів і технічних засобів обробки даних.

Таблиця 1

\section{Формування нової парадигми обліку (розробка авторів)}

\begin{tabular}{|c|c|c|}
\hline Етапи парадигми обліку & Характер досліджень & Період \\
\hline Допарадигмальний & $\begin{array}{c}\text { Зародження та розвиток перших цивілізації. } \\
\text { Зародження і ріст економіки - сільського } \\
\text { господарства, ремесла, торгівлі }\end{array}$ & $\begin{array}{l}\text { Від перших цивілізацій } \\
\text { (IV-III тисячоліття до } \\
\text { н.е.) і до XIII-XIV ст.н.е. }\end{array}$ \\
\hline $\begin{array}{c}\text { Формування старої } \\
\text { парадигми }\end{array}$ & $\begin{array}{c}\text { Л.Пачолі «Трактат про рахунки і записи» (1494). } \\
\text { Розвиток держав Європи. Зародження } \\
\text { промисловості, ріст міст, бурхливий розвиток торгівлі }\end{array}$ & XV-XVIII ст. \\
\hline Нормальна наука & $\begin{array}{c}\text { Узагальнення в обліку окремих корисних } \\
\text { нововведень, що не грунтуються на теорії, але цінні } \\
\text { для бухгалтерії капіталістичного суспільства }\end{array}$ & XVIII-XIX ст. \\
\hline $\begin{array}{l}\text { Протиріччя нормальної } \\
\text { науки }\end{array}$ & $\begin{array}{c}\text { Зростання масштабів виробництва, досягнення } \\
\text { науки, техніки, технології, організації праці та } \\
\text { управління, збільшення невирішених проблем обліку }\end{array}$ & $\begin{array}{c}\text { Кінець XIX - 70-ті роки } \\
\text { XX ст. }\end{array}$ \\
\hline Криза & $\begin{array}{c}\text { Відсутність нових ідей в нормальній науці щодо } \\
\text { генерування інфоормації для управління. Критика } \\
\text { «єдиного обліку». Дискусії щодо удосконалення } \\
\text { обліку }\end{array}$ & $\begin{array}{l}\text { 70-80 ті роки XX } \\
\text { століття }\end{array}$ \\
\hline Революція & $\begin{array}{l}\text { Неспроможність старої парадигми адекватно } \\
\text { відображати потреби бізнесу та суспільства }\end{array}$ & $\begin{array}{c}\text { 90-ті роки XX ст. - до } \\
\text { наших днів }\end{array}$ \\
\hline $\begin{array}{c}\text { Формування нової } \\
\text { парадигми }\end{array}$ & $\begin{array}{c}\text { Демонтування старої парадигми та формування } \\
\text { нової }\end{array}$ & Початок XXI ст. \\
\hline
\end{tabular}

Таблиця 1 показує лише загальний тренд розвитку системи обліку, тому слід застерегти читача від прямолінійного сприйняття наведеної інформації. Зрозуміло, що в історії важко виділити окремі етапи розвитку, оскільки події в них можуть накладатися, повертатись через певний час назад, відхилятися від прямої лінії, повторюватися з певним інтервалом, існувати паралельно тощо. Саме поняття «парадигма» досить метафоричне, свідчить про деякий конструкт, шаблон, загальноприйнятий взірець, за яким створена система для практичної діяльності. Парадигма не може абсолютно точно відтворити реальні події чи розкрити свою сутність як щось матеріальне, вона лише указує на усереднений абстрактний образ науки, як ідеальне існуюче в мисленні людини, яке наближено до істини дає уяву про систему.

Це філософське поняття вимагає від читача певної культури мислення, вміння абстрагуватися від випадкового, несуттєвого і тимчасового та синтезувати різнорідні нюанси 
розвитку системи на певному історичному етапі її існування в певні образи, вектори, тенденції, закономірності тощо.

Проте, бухгалтери не мислять по-фрілософськи, а будь-які абстракції переводять у вузьку «прагматичну» площину, внаслідок чого вихолощують об'єктивну істину заводячи ії до звичних заучених схем того ж самого «бухгалтерського» обліку з його примітивним стилем мислення конкретними образами і убогим інструментальним набором для обробки даних. Усе зводиться до питань як відобразити на рахунках ті чи інші фракти і залишають нез'ясованою проблему, що обробляти і для кого, хоча саме в цьому закладено зміни в обліку, які обумовлюють появу нової парадигми внаслідок кризи старої, яка не могла справитися з вирішенням названих принципових проблем.

Причина консервування старої парадигми обліку криється також у неадекватній назві науки - «бухгалтерський облік, що жодним чином не пов'язана з предметом дослідження - вимірюванням фактів фінансової і господарської діяльності та отриманням на їх основі інформації для менеджерів. «Бухгалтерський облік» відображає лише стандартні процедури (алгоритми) руху ресурсів і здійснення процесів господарювання, кругообороту капіталу, формування собівартості продукції у грошовому вимірнику. При цьому, найважливіші питання тактики і стратегії розвитку підприємства, підготовки інформаційних ресурсів для менеджменту нижчого і вищого рівнів управління, аналізу факторів впливу середовища на результати роботи та інші аспекти інформаційної сфрери підприємства повністю ігноруються обліковим апаратом.

Назва науки, яка прийшла до нас з далекого минулого від німців, вказує на рутинне ремесло маніпуляцій цифрами і процедурами їх обробки, що не відповідає меті обліку в наш час, коли економісти зрозуміли цінність такого, невідомого до 70-х років XX ст. фактора виробництва, як інформація. В постіндустріальному суспільстві, яке формується в наші дні, найважливішим елементом виробництва стають інформаційні ресурси, тому облік, як систему генерування інфрормації, необхідно трансфрормувати на новій парадигмі разом із присвоєнням науці іншої назви.

Бухгалтери досить часто ототожнюють науку із знаннями, що можливо й обумовило назву науки про облік, як мистецтво записів у книги, але наука знаходиться у діалектичному зв'язку відомого і невідомого, коли відомі знання, набуті через освіту, дають поштовх для креативного мислення і проникнення у нові невідомі сфрери реальності. На жаль, «бухгалтерський» облік обмежується лише передаванням фахівцям формальних знань зі збору й обробки даних і не ставить за мету розширення знань на основі креативного мислення, тому облік не став наукою. Акцентування уваги на мистецтві подвійного запису даних у книги відбивається у старій назві обліку і тому переключення уваги на інформацію, як сервісного продукту для менеджменту, не сприймається бухгалтерами, Отже, наука із старою назвою «бухгалтерський облік» в новому економічному середовищі бізнесу закономірно потребує нової назви.

Відкидаючи заперечення з боку ортодоксальних науковців щодо необхідності кардинальної трансформації облікової науки, уважаємо за доцільне віднести облік до числа інформаційних наук, оскільки ії основна функція полягає в генеруванні інформації про діяльність кожного окремого підприємства, хоча й, поки що, обмежену вартісним вимірюванням фрактів. Проте, у найближчій перспективі, за умови формування нової парадигми науки, облікова система повинна орієнтуватися на інформаційне обслуговування системи менеджменту на основі комп'ютерної техніки, що дозволить поглибити і розширити масив інформаційних ресурсів для них. За якісними і кількісними параметрами інформація нової «інформаційної системи обліку» буде кардинально іншою, ніж у традиційній «бухгалтерській», оскільки вона включить в орбіту своїх інтересів найрізноманітніші стандартні й оригінальні методи збору фактів про середовище, події у межах і за межами підприємства та створення повідомлень на індивідуальні запити користувачів. Нові технології блокчейна, хмарних та фрактальних обчислень, які стають практичною реальністю в наші дні, можуть бути з успіхом упроваджені в систему обліку, що дозволять пізнавати взаємовплив одних систем чи їх елементів на інші та швидко адаптуватися до змін і нештатних ситуацій в економіці. 
Нова система обліку з розширеними інформаційними функціями не може розвиватися без перейменування застарілої назви облікової науки «бухгалтерський облік». Зміна назви окремих наук в історії людства $є$ закономірним процесом, в якому науковці приймають активну участь. Заміна назви науки історично обумовлюється переосмисленням її змісту на такому переломному періоді, коли стара назва уводить дослідників від актуальних проблем практики до схоластичних дискусій, які нічого спільного не мають 3 подальшим розвитком наукових знань. Назва «бухгалтерський облік» не відображає ні предмету, ні сутності облікової науки, оскільки 3 німецької слово «buchgaltung» дослівно перекладається як «ведення книг». Як можна предметом обліку називати книги, коли книги в різних аспектах вивчають такі науки, як поліграфрія, бібліотекознавство, філологія, редакторство тощо?

Тільки ігнорування законів логіки і здорового глузду та затятість бухгалтерів $є$ перешкодою для зміни назви облікової науки на благозвучне слово, яке розкриває сутність вчення про інформацію. Тривіальні розповіді бухгалтерів про окремі процедури зі збирання, групування та маніпулювання даними, підміняє зміст науки простими емпіричними правилами опрацювання отриманих фрактів господарської діяльності. Подібно до того, як алхімію у XVIII ст. було перейменовано на хімію, так і «бухгалтерський облік» необхідно назвати таким словом, що розкриває сутність науки, основним завданням якої потрібно визнати отримання різноманітної оригінальної інформації для бізнесу.

Нам видається логічною та умотивованою пропозиція назвати облікову науку виходячи 3 того, що в нашу епоху її сутність полягає в генеруванні інформації, а тому правомірно дати їй назву «інформологія», що розшифровується як вчення (логос) про інформацію (лат. Informo - надаю форму; сприяю створенню уяви про щось; зображую).

Інформологія вказує на предмет науки - створення інфрормації про багатоаспектну діяльність підприємства у просторовому і часовому вимірах. У цій науці знайдеться місце таким підсистемам обробки даних і перетворення їх в інформацію, як фінансова (генерує інформацію у традиційному, звичному для бухгалтерів режимі обробки даних у грошовому вимірнику на рахунках обліку методом подвійного запису. Так що турбуватися моїм опонентам з приводу того куди подінуться бухгалтери з їх стереотипним мисленням не варто, вони займуть своє скромне місце інформології в якості однієї з підсистем.

Консерваторам необхідно подумати про те, що стане з цією професією в найближчому майбутньому, оскільки, за прогнозами футурологів і фахівців, у звичному для нас вигляді «бухгалтерський» облік у 2030-х роках відімре, тому зміна назви облікової науки і наповнення її новим змістом видається не надуманою, а дійсно актуальною проблемою розвитку теорії, практики та підготовки облікових кадрів, здатних реагувати на запити тих, для кого фінансова і не фінансова інформація відіграє таке саме значення, як хліб в житті людини.

Недооцінка проблеми зміни назви облікової науки консервує відставання теорії від сучасного рівня практики тому, що в реальній економіці, а не тій віртуальній, яка укорінилася в головах бухгалтерів, відбуваються кардинальні зрушення, особливо в інформаційній сфері.

Часто менеджери самі відшукують необхідну інформацію для виконання своїх функцій (планування і прогнозування; організації бізнес - процесів; мотивації працівників і контролю) не сподіваючись на облікову службу, яка концентруючи увагу на показниках стандартної фінансової звітності за минулі періоди, не може дати для них ніяких повідомлень про події в реальному часі та перспективі.

Одна із причин відсутності сучасної теорії процесу вимірювання фактів господарської діяльності та їх трансформування в інфрормаційні ресурси для менеджменту полягає у незадовільній підготовці наукових кадрів з облікового напряму. Мій, більш, ніж п'ятдесятирічний досвід практичної, педагогічної та наукової роботи дає підставу зробити висновок про існування в академічному середовищі науковців з облікових, аналітичних та контрольних наук махрового консерватизму, який робить безнадійною справою прищеплення будь - яких нововведень у 
десятиліттями незмінні навчальні програми з курсу теорії обліку, хоча на словах вони за оновлення, а насправді тиражують знання сторічної давності, які відірвані від економічного життя [16].

Слабкість теорії обліку гальмує розробку теорій тих наук, для яких облікова інформація служить у якості об'єкта дослідження - планування, організації, мотивації, аналізу, фінансового й операційного аудиту, контролю, економічної експертизи, технологій обробки даних тощо [17; 18].

Бухгалтери звели облікову науку до простого ремесла, яке незрозуміле представникам інших наук, непосвячених у цю сфреру діяльності, тому воно видається їм загадковим, утаємниченим, чаклунським знанням, у яке вони не втручаються, хоча й повинні ним цікавитися. Облікові знання настільки примітивні, що коли їх можна осягнути за надзвичайно короткий час, навіть без сторонньої допомоги, про що свідчать книги відомих авторів [19; 20; 21].

Якщо можна вивчити облік за один чи два тижні, як це засвідчують автори названих книг, то чому його вивчають цілих п'ять років на економічних факультетах університетів? Мабуть тому, що за логікою настала пора викладати студентам облікових факультетів університетів не примітивний «бухгалтерський облік», який практично є ремеслом, а складну інтелектуальну систему, яка здатна створювати оригінальний набір інфрормації на запити будь - яких користувачів. Така облікова надсистема повинна включати, принаймні, три підсистеми - фінансового, управлінського і стратегічного обліку. Зрозуміло, що для неї необхідно розробити абсолютно нову теорію на основі філософрського осмислення ролі обліку в суспільстві та бізнесі, як сервісної інформаційної системи для управління, яку можна створити лише на основі теорії наукового пізнання.

\section{Висновки і перспективи.}

Нову теорію можна створити лише в тому випадку, коли ми радикально змінимо саму назву теперішньої облікової науки, оскільки вона завжди буде акцентувати увагу на процедурах збору й обробки фактів господарської діяльності, а не змістовних аспектах підготовки інформаційних ресурсів для потреб менеджерів.

3 філософських позицій людина пізнає явище за допомогою своїх органів відчуття, що становить емпіричний (нижчий) ієрархічний рівень у процесі пізнання реальності, а сутність - за допомогою розуму, його здатності виробляти судження про речі, явища і процеси цієї реальності, що являє собою вищий рівень пізнання. Сучасна облікова наука застрягла на емпіричному рівні пізнання, що й знаходить свій відбиток у такій назві, як «бухгалтерський облік», що акцентує увагу на зовнішніх і другорядних аспектах облікових явищ. Проте, сутність науки полягає в інформаційному процесі без якого неможливо уявити економічне життя та закономірності розвитку бізнесу, а не у веденні книг належним чином, як зазначав Л. Пачолі ще у XV ст.

Інформація служить єдиним джерелом приведення хаосу в порядок, зниження рівня ентропії (невизначеності) у функціонування системи і флуктуацій середовища та протидії деструктивним факторам розвитку системи, які можуть знову перетворити порядок у хаос. Отже, вирішити складних питання генерування інформації в економічних системах може лише нова наука, яка в центр пізнання ставить інформацію та інтереси їі користувачів, а процедури збору й обробки фактів відсуваються на другий план. У зв'язку з цим пропонуємо обліковій науці дати назву «інформологія»

У теорії інформології, як науці про формування інформаційних ресурсів для менеджменту, у знятому вигляді у відповідності до діалектичного закону заперечення заперечення будуть відтворені ті елементи пізнання дійсності, які притаманні існуючому фінансовому обліку і, крім нього, кожній з нових підсистем (управлінській і стратегічній). Разом 3 цим, облікова наука «інформологія» набуде нових властивостей на основі принципу синергії, коли загальний ефект від створення цілісної системи перевищує суму ефектів від окремих її підсистем.

\section{Список використаних джерел}

1. Теорія бухгалтерського обліку: монографія ; за ред. Л.В.Нападовської. Київ : КНТЕУ, 2008. 735 с. 
2. Теорія бухгалтерського обліку: підручник ; за ред. Ф.Ф.Бутинця. 2-ге вид., доп. і перероб. Житомир: ЖITI, 2000. $640 \mathrm{c}$.

3. Білуха М.Т. Теорія бухгалтерського обліку: підручник. Київ : КНТЕУ, 2000. 692 с.

4. Теория бухгалтерского учета; под ред. Б.И. Валуева. Одесса: Принт-Мастер, 2002. 272 с.

5. Ткаченко Н.М. Бухгалтерський фінансовий облік, оподаткування і звітність: підручник. 2-ге вид. доп. і перероб. Київ: Алерта, 2007. 952 с.

6. Сопко В.В. Бухгалтерський облік: навч. посіб., 3-тє вид., перероб. і доп. Київ : КНЕУ, 2000. 578 с.

7. Швець В.Г. Теорія бухгалтерського обліку: підручник. Київ : Знання, 2004. 447 с. 2009. $648 \mathrm{c}$.

8. Жук В.М. Концепція розвитку бухгалтерського обліку в аграрному секторі економіки. Київ : HНЦІАЕ,

9. Малюга Н.М. Бухгалтерський облік в Україні: теорія й методологія, перспективи розвитку: монографія. Житомир: ЖДТУ, 2005. 348 с.

10. Легенчук С.Ф. Парадигмальний метод Т.С.Куна в бухгалтерском учете. Бухгалтерский учет, контроль и анализ: социальные ориентиры: монография ; под общей ред. Ф.Ф.Бутынца. Житомир: ЖГТУ, 2008. $-484 \mathrm{c}$.

11. Пушкар М. С., Чумаченко М. Г. Ідеальна система обліку: концепція, архітектура, інформація: монографія / М.С.Пушкар. - Тернопіль: Карт-бланш, 2011. 336 с.

12. Бруханський Р.Ф. Облік і аналіз у системі стратегічного менеджменту аграрного підприємства монографія. Тернопіль: ТНЕУ, 2014. 384 с.

13. Семанюк В. 3. Формирование парадигмы учета в постиндустриальном обществе. Вестник Полоцкого государственного университета. Сер. D, Экономические и юридические науки: научнотеоретический журнал. - Новополоцк : ПГУ, 2012. № 14. С. 56-62.

14. Нонака И., Такеучи Х. Компания - созидатель знания. Москва : ЗАО «Олимп-бизнесс», 2003. 211 C. 2009. $310 \mathrm{c}$.

15. Кун Т.С. Структура научных революций: пер. с англ. И.З.Налетова. Москва : АСТ: АСТ Москва,

16. Сучасні проблеми розвитку системи обліку в Україні: монографрія ; за ред. Пушкаря М.С. Тернопіль: ТНЕУ, 2010. 268 с. 2014. - 140 c.

17. Пушкар М.С. Теорія пізнання у розвитку науки про контроль: монографія. Тернопіль: Карт-бланш,

18. Аудит: навчальний посібник ; за ред. Пушкаря М.С. Тернопіль: Карт-бланш, 2011. 275 с.

19. Молчанов С.С. Бухгалтерский учет за 14 дней. Экспресс-курс. Москва : ЭКСМО-Пресс, 2009. 480 с.

20. Гартвич А.В. Бухгалтерский учет за 10 дней. Москва : Проспект, 2009. 264 с. $336 \mathrm{c}$.

21. Бухгалтерский учет: интенсивный курс за 7 дней ; под ред. Н.А. Каморджановой. Спб: Питер, 2009.

Статтю отримано: 24.01.2017 / Рецензування 25.02.2017 / Прийнято до друку: 17.05.2017

\section{Mykhailo Pushkar}

Dr.Sc. (in Economics), Professor

Department of Audit, Control and Analysis

Ternopil National Economic University

Ternopil, Ukraine

E-mail: M.S.Pushkar@gmail.com

Vita Semanyuk

Ph.D. (in Economics), Associate Professor

Department of Audit, Control and Analysis

Ternopil, Ukraine

E-mail: v.semaniuk@tneu.edu.ua

\section{RESEARCH ON ACTUALITY OF UP-TO-DATE ACCOUNTING PARADIGM}




\section{Abstract}

Introduction. Society and business can't exist without accounting system, which contains the information about financial and business activities at the microeconomic level and transforms it into useful knowledge in enterprise management. However, the existing model of universal "accounting" is out of date due to applying the only method of double entry book keeping, not taking into account the abilities of data collection and organization with the help of modern computer technologies, such as block chains, cloud computing, artificial intellect that demand the development of new paradigm.

Methods. The Platonism methods such as laws of dialectic, logics, historical, sociologic and system approach to accounting science analysis and its paradigm, accounting development projection as a complicated dynamic system, factors of accounting comity prudence were used in the study.

Results. The analysis of historical development of accounting science and practice in Ukraine shows its inconsistency to economic system formed after 1991. The accounting paradigm contains the characteristics of previous century. It is based on principles of manual data processing and getting the enterprise information in money terms. Such information allows only managing the financial activities. To manage the business activities at operational and strategic levels "accounting" doesn't provide any information. So, the old accounting paradigm should be replaced by up-to-date one. The system must generate the information for all management levels. Taking into account the fact that a manager needs different information in time, structure and volume, the development of up-to-date new information paradigm should be based on creating the complex dynamic system with financial, management and strategic accounting. Besides, "accounting" should be rebrand in "information science" to prepare old system accountants for new type of thinking and activities. As the result, the revolution changes in paradigm are of vital importance not to consider the accounting to be art of book records and accounting document.

Discussion. The development of accounting science is impossible without refocusing from stereotyped way of data processing for financial reports to a system of getting the information of intellectual level for management.

Keywords: science, dialectic, paradigm, accounting system, accountant point of view, accounting subsystems, information science

\section{References}

1. Napadovska, L.V. (Ed.). (2008). Teorija buhgalters'kogo obliku: monografija [Theory of Accounting: monograph]. Kyiv : KNTEU.

ZhITI.

2. Butinec, F.F. (Ed.). Teorija buhgalters'kogo obliku (2000). [Theory of Accounting (2-nd edition]. Zhitomir:

3. Biluha, M.T. (2000). Teorija buhgalters'kogo obliku [Theory of Accounting]. Kyiv : KNTEU.

4. Teorija buhgalterskogo ucheta; pod red. B.I. Valueva (2002) [Theory of Accounting; Ed. B.I. Valuev]. Odessa: Print-Master.

5. Tkachenko, N.M. (2007). Buhgalters'kij finansovij oblik, opodatkuvannja i zvitnist'. 2-ge vid. dop. i pererob. [Accounting, taxation and reporting (2-nd ed.)]. Kyiv: Alerta.

6. Sopko, V.V. (2000). Buhgalters'kij oblik: 3-te vid., pererob. i dop. [Accounting (3-d ed.)]. Kyiv : KNEU.

7. Shvec, V.G. (2004). Teorija buhgalters'kogo obliku [Theory of Accounting]. Kyiv : Znannja.

8. Zhuk, V.M. (2009). Koncepcija rozvitku buhgalters'kogo obliku v agrarnomu sektori ekonomiki [The concept of development of accounting in the agrarian sector of the economy]. Kyiv : NNCIAE.

9. Maljuga, N.M. (2005). Buhgalters'kij oblik v Ukraïni: teorija j metodologija, perspektivi rozvitku: monografija [Accounting in Ukraine: theory and methodology, development prospects: monograph]. Zhitomir: ZhDTU.

10. Legenchuk, S.F. (2008). Paradigmal'nij metod T.S.Kuna v buhgalterskom uchete. Buhgalterskij uchet, kontrol' i analiz: social'nye orientiry: monografija ; pod obshhej red. F.F.Butynca [The paradigmatic method of TC Kuhn in accounting. This is a chapter. In F.F. Butynets (Ed.), Accounting, control and analysis: social reference points : monograph]. Zhitomir: ZhGTU.

11. Pushkar, M. S., \& Chumachenko M. G. (2011). Ideal'na sistema obliku: koncepcija, arhitektura, informacija: monografija [The ideal accounting system: concept, architecture, information: monograph]. Ternopil': Kart-blansh.

12. Bruhans'kij, R.F. (2014). Oblik i analiz u sistemi strategichnogo menedzhmentu agrarnogo pidpriemstva [Accounting and analysis in the system of strategic management of an agricultural enterprise]. Ternopil': TNEU.

13. Semanjuk, V. Z. (2012). Formirovanie paradigmy ucheta v postindustrial'nom obshhestve [Formation of a paradigm of accounting in a postindustrial society]. Vestnik Polockogo gosudarstvennogo universiteta. Ser. D, Jekonomicheskie i juridicheskie nauki: nauchno-teoreticheskij zhurnal, 14, 56-62.

14. Nonaka, I., \& Takeuchi, H. (2003). Kompanija - sozidatel' znanija [The company is the creator of knowledge]. Moskow : ZAO «Olimp-bizness». 
15. Kun, T.S. (2009). Struktura nauchnyh revoljucij: per. s angl. I.Z.Naletova [The structure of scientific revolutions (I.Z.Naletov, Trans.)]. Moskow : AST.

16. Pushkar, M.S. (Ed.). (2010). Suchasni problemi rozvitku sistemi obliku v Ukraïni: monografija [Modern problems of development of the accounting system in Ukraine]. Ternopil': TNEU.

17. Pushkar, M.S. (2014). Teorija piznannja u rozvitku nauki pro kontrol': monografija [Theory of knowledge in the development of the science of control]. Ternopil': Kart-blansh.

18. Pushkar, M.S. (Ed.). (2011). Audit [Audit]. Ternopil : Kart-blansh.

19. Molchanov, S.S. Buhgalterskij uchet za 14 dnej. Jekspress-kurs [Accounting for 14 days. Express course]. Moskva : JeKSMO-Press, 2009. $480 \mathrm{~s}$.

20. Gartvich, A.V. (2009). Buhgalterskij uchet za 10 dnej [Accounting for 10 days]. Moskow : Prospekt.

21. Kamordzhanova, N.A. (Ed.). (2009). Buhgalterskij uchet: intensivnyj kurs za 7 dnej [Accounting: intensive course for 7 days]. St. Petersburg : Piter, 2009. $36 \mathrm{~s}$.

Received: 01.24.2017 / Review 02.25.2017 / Accepted 05.17.2017

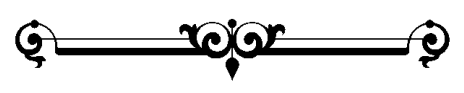

